\title{
Reviews
}

\section{Margery Fee}

\section{So What Do Polar Bears Think about Us?}

Michael Engelhard. Ice Bear: The Cultural History of an Arctic Icon. University of Washington Press, 2017. Xiii, 288 pp. Pb. \$29.95 US

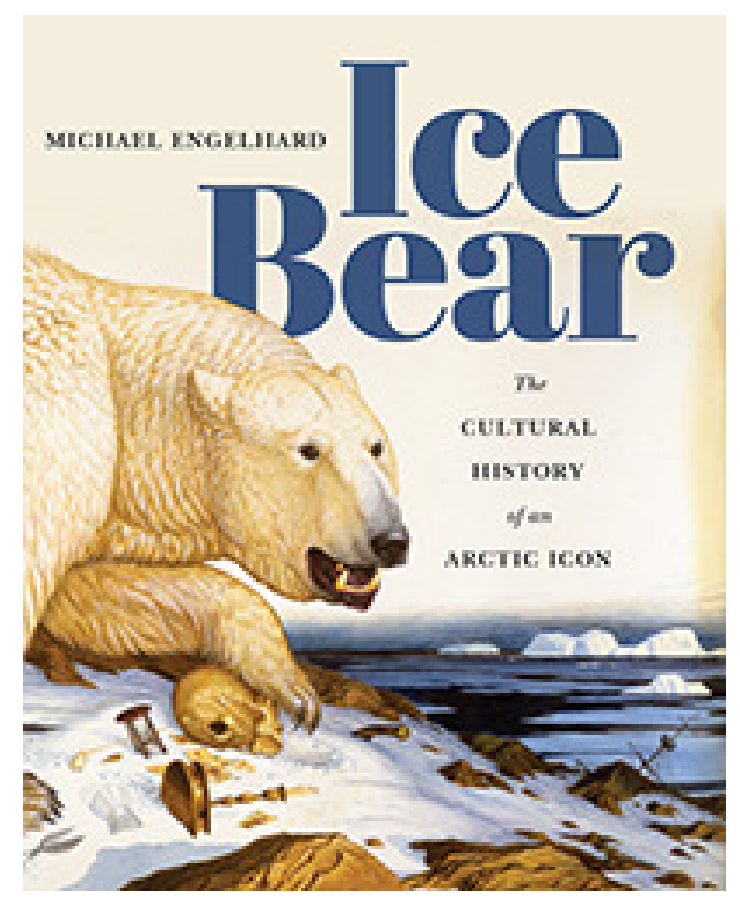

Engelhard's book fills a large gap. Excellent books by Ian Stirling and Andrew Durocher on the biology and behavior of polar bears have been published recently, but the story of the white bear's persistent ability to capture human imaginations has not, until now. been comprehensively tracked. Engelhard is "more interested in attitudes than actions" (72), a focus that puts myths and mistakes before historical and scientific facts. Nonetheless, this work of anthrozoology also contains many facts, both sobering and intriguing. Engelhard's expertise derives from his work as an Alaskan wilderness guide, his graduate degree in cultural anthropology, and his many important nature publications. The book includes a circumpolar map, detailed footnotes, an index, a selected bibliography, and a list of important associations and websites. It is eminently scholarly, citing an impressive array of sources from Icelandic manuscripts to master's theses to records in German. That said, Engelhard's clear and easy style will appeal to general readers, as will the more than 160 well-chosen and often dramatic illustrations. 
The book begins with a timeline that starts with the first documented hunting of polar bears around 8000 years before the present. An introductory overview is followed by the life story of Knut, born in the Berlin Zoo in 2006, whose brief life attracted rockstar levels of attention. Eleven chapters follow, organized by general themes examined in roughly chronological order, recounting stories of bears as early commodities, bears as "man-killers," bears in circuses and zoos, bears in Indigenous hunting cultures, bears as meat, bears as figures of spiritual transformation, bears as symbolic helpers and protectors, bears as icons of sexuality, bears in new-age totemism, particularly as symbols of climate change, and bears as tourist attractions.

As Engelhard makes clear in his introduction, the intersection of modern humans and polar bears has led to a depressing history of slaughter, beginning in the late nineteenth century, when whalers and sealers found themselves in the far north. Polar bears provided meat, fur, and an extra income through sales of living animals to circuses and zoos, and pelts, skulls, teeth, and claws as exotic trade commodities. The bears were killed from boats and later, planes, or with traps that relied on the bear's natural curiosity to attract them. In 1973, the "Polar Bear Nations" of Canada, the Soviet Union, Norway (Svalbard), the United States and Denmark (Greenland) signed the "Agreement on the Conservation of Polar Bears" to limit hunting, permitting it only for scientific study, in self-defence, or by indigenous hunters using traditional methods. The International Union for the Conservation of Nature (IUCN) Polar Bear Specialist Group first listed the bears as vulnerable in 2006 and reaffirmed this assessment in 2015. However, despite this judgment, the Convention on the Trade in Endangered Species (CITES) - failed to ban trade in polar bear parts in 2010.

Writing a detailed cultural history covering a diverse array of cultures over a long period is a tough task. No real narrative through-line is possible here, given the many ways that polar bears have been represented-from snarling monster to wide-eyed children's toy - and the array of locations where humans have encountered them, from bear pits to ice floes. Engelhard describes himself as "a historian of world-views," who believes "that invented attributes or incidents reveal our values and psychological needs even more clearly than purely historical records, because they require so much creative effort" (34). He deals with an astonishing array of creative and intellectual effort and his accounts, studded with engaging detail, will certainly inspire further reading.

For example, Londoners became familiar with polar bears after Henry III received one as gift from the King of Norway; it was kept in the menagerie in the Tower of London. Chained by the neck, it fished for itself in the Thames. Polar bears were kept in the 
Tower until 1808. Engelhard argues that "in the 1610-11 theatrical season, polar bears could have starred in three Shakespeare productions" (42). Since theatre impresario Philip Henslowe and his actor son-in-law had a royal warrant to keep two white bears, this case is not implausible. Given their owners, these bears certainly are early figures in a long history of performing bears, also carefully documented in the book, a history now nearly ended by animal rights activists.

Engelhard's overview of paintings from the age of British exploration includes one representing a young Nelson clubbing a polar bear with the butt of his rifle. Humans exaggerate the danger of any animal that has attacked or killed a human although men kill far more polar bears than the reverse. Early explorers did have frightening encounters with polar bears, to be sure, and managed to convey their terror to an audience eager for sensational news of far-off lands. Herman Melville, creator of another white threat, is quoted: "Witness the white bear of the poles, and the white shark of the tropics: what but their smooth, flaky whiteness makes them the transcendent horrors that they are...?" (qtd. 76). Edwin Henry Landseer's "Man Proposes, God Disposes" (1864) depicts polar bears on the wreck of one of the ships of Captain Sir John Franklin's 1845 polar expedition, tearing at a flag and snarling at a skeletal human rib cage. His overview of the representations of Franklin's and many other arctic expeditions not only documents the toll they took on the real polar bear population, but also highlights the racist conflation in many depictions of the Inuit and the bears as equally savage or primitive. Engelhard convincingly depicts how the polar bear reigns in what he calls a "geography of fantasy," a requisite feature of arctic representations. Once a terrifying and distant threat, the polar bear and the peoples associated with it were rendered familiar in the twentieth century for southern audiences in circuses, zoos, world's fairs, photographs, and films.

Although primarily focused on Western representations, Engelhard also delves into Indigenous beliefs and practices around polar bears. The Inuit have always believed that polar bears have "isuma," intelligence, and say that the polar bear taught them how to hunt seals. As Engelhard notes, for them the polar bear "is but one strand in a web of kinship, competition, and obligation" (121). They hold a widespread Indigenous belief that animals are more powerful than humans and deserve immense respect. For them, eating polar bear meat is a reaffirmation of community, and Engelhard notes that their views should not be conflated with those of incomers with different perspectives.

Who knew that Darwin credited someone besides Alfred Russel Wallace with the independent discovery of the theory of evolution? James Lamont deduced that polar

Humanimalia: a journal of human/animal interface studies

Volume 9, Number 1 (Fall 2017) 
bears must have evolved from brown bears, since polar bears require a diet of fatty seals to survive the cold. Thus, he reasoned, seals must have evolved first, and then polar bear then evolved from brown bears driven into the north by starvation or climate shift. Indeed, recent hybrids between polar bears and grizzlies have been reported, and DNA testing has revealed that this process of evolution and hybridization means the polar bear's family tree is tightly integrated with that of terrestrial bears. And there is much more to learn and reflect on in this engaging book. 